doi:10.26529/cepsj.723

\title{
Editorial
}

\section{Curriculum Development in Contemporary Society}

Educational reforms are underway in a number of countries. As a prominent factor in societal development as well as in the personal development of individuals and their preparation for life in society, education has a significant task and role in society today.

The question of the national curriculum is largely a question of what kind of society we live in and what kind of society we want to create to provide a context for the full development of individuals as human beings. This is especially true of the curriculum, which is part of the essence of the education system.

As has been stated by Andy Hargreaves (2003), Manuel Castels (1996), Daniel Bell (1999), and many other social theorists, today's society is currently at a turning point from an industrial society to a post-industrial and knowledge-based society. We are consequently witnessing the emergence of a knowledge-intensive economy and the globalisation of markets and capital, accompanied by intense competition and rapid changes in knowledge and technology. According to Roger Standaert (2003), these are some of the current developments that have brought about significant structural changes in society and its sub-areas, as well as in the personal lives, lifestyles, and social relations of individuals.

Facing new challenges, educational policies have seeking educational changes that will respond to these developments, including adjusting national curricula to the needs of the knowledge-based society.

Connecting educational changes with the currently dominated neoliberal politics and neo-conservativism, Michael W. Apple (2004) points out that the current educational reforms lead to the imposing of national curricula, the mechanisms of standardisation and evaluation of students learning outcomes and quality of schools, that is, the regulation of education that ensures the privilege of students with a higher socio-economic and cultural status, thus contributing to the educational and social inequality.

The process of planning and implementing national curricula is a complex process, economically, politically, and socially. It raises numerous issues at individual and societal levels and requires continuous and critical theoretical and empirical analysis.

Within that context in this focus issue of the CEPS Journal are questions such as: What are the goals of educational and curricular policy? What is the purpose of curriculum change? What competences will students need 
in the future as individuals living in an increasingly changing and uncertain society? What kind of knowledge and learning/teaching practices and environments should be provided? How can an inclusive and just national curriculum be ensured? How can relevant curricular stakeholders (e.g., teachers, school leaders, parents, students) be prepared for and included in curricular change and its implementation?

The intention of this special issue of the CEPS Journal is to critically reflect on these and other questions related to today's curriculum and its development in different educational and societal contexts from various scientific perspectives. The issue consists of eight contributions: five of them relate to the Journal's call for papers (focus section), two are in the varia section, and one is a book review.

The first paper, The Heritage of the Cold War in Contemporary Curricula and Educational Reforms by Tomislav Topolovčan and Snježana Dubovicki, deals with the implications of the Cold War, including the military race, on national curricula and educational reforms implemented in the second half of the $20^{\text {th }}$ century and the $21^{\text {st }}$ century. The implications of the Cold War in relation to the concept and development of the socio-humanistic curriculum have also been examined. Analysing the conceptual and historical development of the curriculum, the paper discusses the connection of the Cold War requests/ needs for scientific and technological development with an increasing role of behavioural psychology in the growth of new teaching and learning approaches, with turnaround towards the quantification of learning outcomes and quality of education. The analysis also points out that these processes were followed by the domination of the Anglo-Saxon concept of curriculum at the expanse of the historical European concept of education, mostly based on German didactic thought of humanistic approaches to education and curriculum. Such developments have resulted in a reduction of the socio-humanistic content in national curricula and increased the importance of the STEM area, in a lack of humanistic and holistic approach towards education. A significant conclusion of the paper is that there is a need for broad discussions on the impacts of the Cold War on the development of modern education and curricula in current society. In this context, this challenging paper opens up questions about the implications of the Cold War on the development of education in relation to other contemporary social trends, such as neoliberalism.

The second paper, Understanding the Relation of Policy Discourse and Re-Conceptualising Curriculum: A Kosovo Perspective on a New Meaning of Context by Blerim Saqipi, is focused on an analysis of the meaning of context in the process of implementing curriculum reforms. The analysis is carried out on 
two Kosovo curriculum reforms in the previous two decades with the purpose of demonstrating how education systems deal with the transfer of international ideas and policy models and struggle for their successful implementation. To determine the policy orientation of the reforms, the curriculum policies from 2001 and 2011 were used as units of analysis and examined using the debate between the Didaktik Theory and Curriculum Theory Traditions. Work plans and reports of the Ministry of Education, Science and Technology were used to analyse the implementation practice for 2011 curriculum implementation. Discursive institutionalism was used as a framework for their analysis. To identify the challenges and impacts of the societal and educational context on the success of the curriculum reforms, the contextual factors were also explored. The analysis reveals that the Kosovo context and education system did not succeed in providing sufficient possibilities for a successful implementation of the curriculum reforms. The education system, with its limited professional capacities and scarce resources, points to the need for more school-based activities and critical reflection on the adopting and tailoring of specific curriculum policies and models in the given context.

The third paper relating to the main topic of this issue, Curriculum Reform in Indonesia: Moving from an Exclusive to Inclusive Curriculum by Amirul Mukminin, Akhmad Habibi, Lantip Diat Prasojo, Abdullah Idi and Afreni Hamidah, analyses the national curriculum in Indonesia, questioning the possibilities of its transition from an exclusive to inclusive curriculum so that all students can succeed academically and socially. In addition to the definitions of an exclusive and an inclusive curriculum, the study seeks to answer the question of what components of the national curriculum should be reformed, and what kind of leadership is needed to successfully reform it from an exclusive to an inclusive curriculum. The analysis provides a very informative description of the development of the national curriculum in Indonesia from 1968 to 2013. As a solution, the paper proposes the ASPIRE model of inclusive leadership as well as a model of an inclusive curriculum that consists of the following components: developing different historical perspectives, different cultural awareness, developing intercultural competence, combating racism, sexism, all forms of prejudice and discrimination, raising awareness of the state of the planet and building social skills. Although the article is focused on the Indonesian curriculum, it contributes to the development of an inclusive curriculum in a broader context, especially in multicultural countries that have a centralised exclusive national curriculum.

The paper entitled Teachers' Acceptance of Curriculum Reform in the Czech Republic: One Decade Later written by Karolína Pešková, Michaela 
Spurná and Petr Knecht contributes to the main topic by analysing primary and lower secondary teachers' attitudes towards the current curriculum reform in the Czech Republic. The paper is based on the results of empirical research carried out on a sample of 701 teachers in 2016. A questionnaire was distributed to teachers in an electronic version via headmasters. The main research goals were to identify attitudes of teachers towards the curriculum reform 10 years after its implementation and the factors that influence the teachers' attitudes toward the reform. The results indicate that teachers hold rather negative and neutral attitudes to the reform. Three factors that significantly influence the teachers' attitudes were identified: the approach to the curriculum, school level, and the post that teachers have within the curriculum implementation. According to the findings, the teachers' acceptance of the reform tends to increase when teachers use curriculum documents regularly and have higher self-efficacy. The research results do not point to a significant difference in the attitudes of teachers regarding their gender, the length of the teaching experience, and the involvement of teachers in school management.

The final paper in the focus section, Research-Based Learning in Initial Teacher Education in Catalonia written by Ingrid Agud and Georgeta Ion, discusses changes in the teaching profession in the contemporary society marked by the shift from teachers' role as 'knowledge users' towards their role as 'knowledge creators'. It draws on the preliminary empirical findings of a project focused on an investigation of the development of research competence in initial teacher education, as one of the core teachers' skills. A questionnaire was administered in 2016; 113 students for the Primary Teacher Education Degree at the Universitat Autonoma de Barcelona completed the questionnaire. Also, in order to review the research component of initial teacher education curricula, a documental analysis of the syllabus of each course of the BA in Primary education was conducted. The questionnaire findings indicate that students are more consumers than producers of research. The results of the analysis of the syllabi are in accordance with the questionnaire findings. Specifically, they reveal a very low representation of the research component in the curriculum of the BA programme in teacher education. These preliminary findings indicate the problem of traditional teacher education and emphasise the need for its modernisation as well as the need for a deeper investigation of teacher education.

The VARIA section consists of two papers dealing with teachers and, therefore, is thematically connected with the focus topic of this special issue. The paper, Development of Teachers' Beliefs as a Core Component of their Professional Identity in Initial Teacher Education: A Longitudinal Perspective by Vlasta Vizek Vidović and Vlatka Domović, is a research report presenting the findings 
on the shift in professional beliefs of students attending initial teacher education in Croatia. The focus is on the student teachers who are preparing for class teaching and the shift in their beliefs about the teacher-pupil roles. The research was carried out in two waves, at the beginning and at the end of the five-year study programme, using a metaphor technique derived from the cognitive theory of metaphor; 62 students participated in the project. The findings indicate that the study programme did not have a significant impact on changes in the student's beliefs.

As its title says, the article The Teacher as a Lesson Designer written by Ljerka Jukić Matić also explores teachers. Its main goal is to explain how a mathematics teacher designs a lesson using the mathematics textbook. The research on which the paper is based was designed as a case study. Lesson observations and pre-lessons and post-lessons interviews were conducted. The textbook content was also analysed. The research design draws on the analytical framework created by Leshota (2015). The results indicate that, during lesson planning and the lesson itself, the teacher was using the textbook in a way that demonstrates the teacher's shift from a mediator of the curriculum to a designer of the teaching. Since only one teacher participated in the research, the findings do not allow drawing of general inferences, but they provide an in-depth and extensive description of the researched issue.

This CEPS Journal issue also includes a review on the book: Contextualizing Teaching to Improve Learning: The Case of Science and Geography, Nova Science Publishers: New York, NY, 2017; 303 pp., edited by Laurinda Leite, Luis Dourado, Ana S. Afonso and Sofia Morgado.

BRANISLAVA BARANOVIĆ

References

Apple, W. M. (2004). Creating difference: Neo-liberalism, neo-conservativism and the politics of educational reform. Educational Policy, 18(1), 12-44.

Bell, D. (1999). The coming of post-industrial society. New York, NY: Basic Books.

Castells, M. (1996). The rise of the network society. Oxford, UK: Blackwell.

Hargreaves, A. (2003). Teaching in the knowledge society. New York, NY: Teachers College Columbia

University.

Standaert, R. (2003). Introduction. In R. Standaert (Ed.), Becoming the best. Educational ambitions for Europe (pp. 7-17). Enschede: CIDREE. 